\title{
EVOLUTION OF HYBRID SUPER CAPACITORS AND ITS FUTURE PATHWAY
}

\author{
Meraka Mounika \\ Student \\ Department of EEE \\ GMRIT, Rajam, Andhra \\ Pradesh, Indi
}

\author{
Gullipalli Dilip Kumar \\ Student \\ Department of EEE \\ GMRIT, Rajam, Andhra \\ Pradesh, India
}

\author{
D. Danalakshmi \\ Associate Professor \\ Department of EEE \\ GMRIT, Rajam, Andhra \\ Pradesh, India
}

\begin{abstract}
The social and economic of the nation depend upon fossil fuels such as coal, gas and oil. The depletion of natural resources causes economic problems for the usage of power generation and storage, industrial operations and transportation. Based on these consequences, the development of renewable sources such as solar energy, wind energy, tidal energy, geo-thermal energy and biomass have been increasing for the generation of electricity. Due to rapid development in electronic devices, there is a huge development in the storage devices such as batteries, fuel cells and super capacitors. Among these, hybrid super capacitor is the best energy storing device when compared to other electrochemical cells in terms of all aspects. It is a multifunctional electro chemical device which are highly flexible, stretchable, foldable, wearable, transparent and few more functionalities. This paper discuss about the evolution of hybrid supercapacitors, different types of hybrid supercapacitors, energy densities and power densities of the hybrid supercapacitors, properties, applications in the present generation and their future advancements.
\end{abstract}

Keywords: Batteries, Super capacitors, Hybrid super capacitors, Flywheel, Pumped Hydro, Pseudo capacitors, Double layer super capacitors.

\section{INTRODUCTION}

In 1800 Volta discovered that certain fluids would generate a continuous flow of electrical power. This discovery led to the invention of the first voltaic cell which is commonly known as battery. The word "battery" comes from the old French word batteries which means "action of beating"[1-3].

In 1859, the French physician Gaston Plante invented the first rechargeable battery [4] based on lead acid. Until then, all batteries were primary, meaning they could not be -recharged. Due to this invention there is huge change in the field of energy storage devices.

Later in 1957, engineers at General Electric Company first experimented with an early version of super capacitor, but there were not succeeded. In 1966 again, standard oil company rediscovered the effect of the double-layer capacitor unexpectedly while doing experiments on fuel cell designs. The double-layer greatly improved the ability to store energy and this lead to the evolution of the super capacitors.

In 1978 "supercapacitors" are used for computer memory backup. In the early $20^{\text {th }}$ centuries researches were started on this supercapacitors by using different materials and manufacturing methods which led to improved performance and reducing cost. Due to this there was a great demand for the super capacitors till now. In order to reduce the disadvantages caused by super capacitors they invented the Hybrid super capacitors [5-7].

In this paper, section 2 discuss about the fundamentals and different types of energy storage system, section 3 discuss about the classification of supercapacitors and comparing different energy storing devices, section 4 discuss about the Hybrid Supercapacitors and different types of Hybrid Supercapacitors, section 5 discuss about the construction and working of this Hybrid Supercapacitors, section-6 discuss about the applications of the hybrid super capacitors, section7 is the conclusion which gives the summary and overview on the topic.

\section{FUNDAMENTALS OF ENERGY STORING SYSTEMS}

At present power electronics is became a major part in our life because the electrical devices 


\section{International Journal of Engineering Applied Sciences and Technology, 2019 Vol. 4, Issue 6, ISSN No. 2455-2143, Pages 114-119 \\ Published Online October 2019 in IJEAST (http://www.ijeast.com)}

are incorporated with power electronics for good performance. For this power electronics applications basically require energy storage devices mainly because to use these devices as the primary energy source for power conversion. At present, the following types of energy storing technologies are generally used for various applications [1-3].
a. Flywheel systems
b. Battery systems
c. Superconducting magnetic systems
d. Pumped-hydro system
e. Compressed air systems
f. Super capacitor systems

Flywheel systems:

In this system energy is stored in the mechanical form and this system is used in power quality applications. The below Figure 1 represents the flywheel.

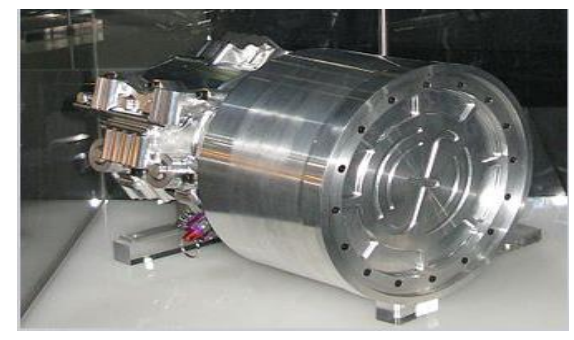

Figure: 1

\section{Battery systems:}

In this systems energy is stored in electrochemical form and this system is used in power systems for power quality and load levelling applications. The below Figure 2 represents the Battery bank.

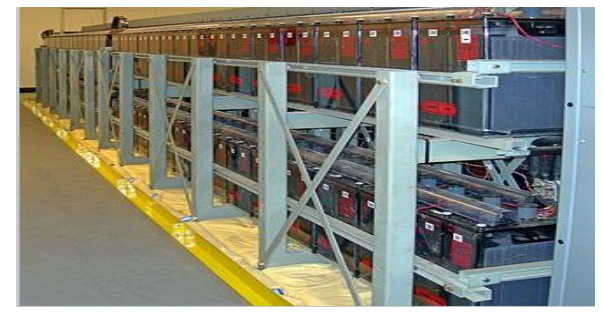

Figure 2

\section{Superconducting magnetic systems:}

In this systems energy is stored in the form of magnetic field form and this system is used in bullet trains. The below Figure 3 represents Bullets Train mechanism.

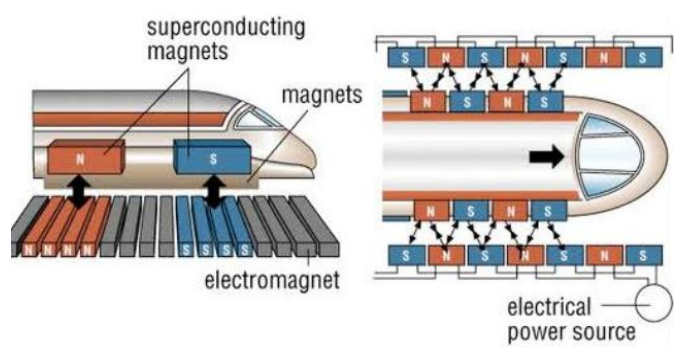

Figure 3

\section{Pumped-hydro systems:}

In this systems energy is stored in the form of potential energy and this system is used in reservoirs. The below Figure 4 represents Pumped storage Reservoir.

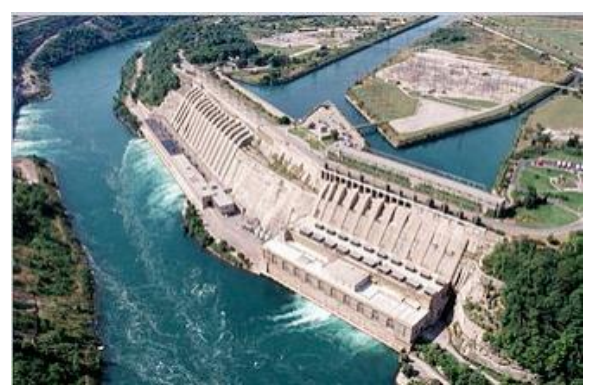

Figure 4

\section{Compressed air systems:}

In this systems energy is stored in the form of kinetic energy and this system is used in gas based power plant. The below Figure 5 represents the Compressed air system. 


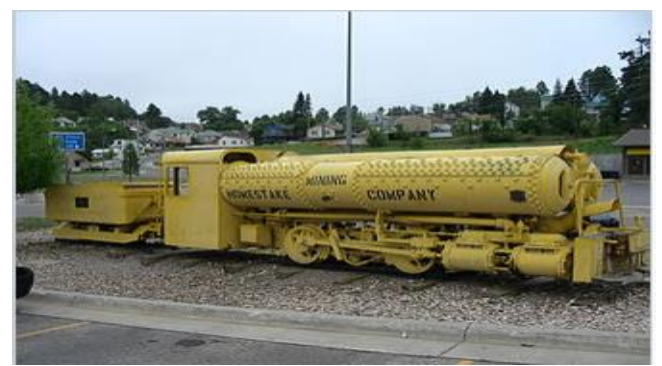

Figure 5

\section{Super capacitor systems:}

In this systems energy is stored in the form of both electrostatic form and electrochemical form and this system is used in automobiles. The below Figure 6 represents the Hybrid Buses.

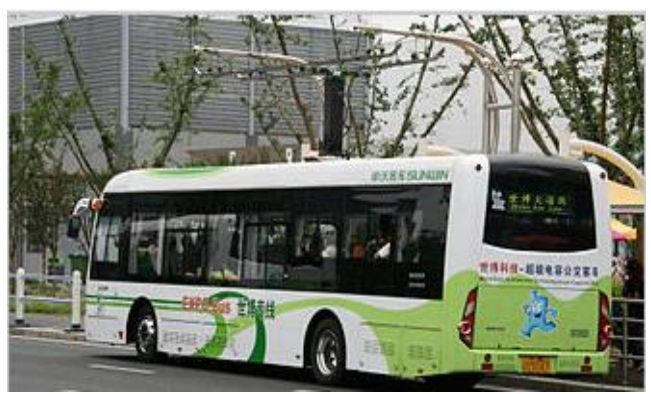

Figure 6

These are some of widely used energy storing techniques in the present's world but they are lot of other energy storing techniques some of them are Hydrogen storage, Biofuel storage, Latent heat thermal energy storage (LHTES) and Sensible heat thermal energy storage (SHTES) etc. The below Figure 7, represents how the power density and energy density of super capacitors

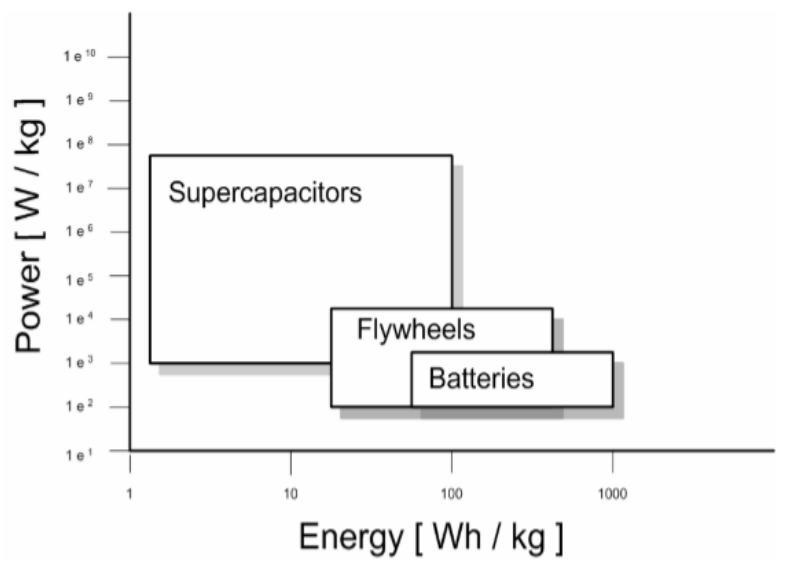

Figure 7

This figure clearly shows that super capacitors are better than Flywheels and Batteries [6-8].

TABLE 1. PROPERTIES OF HYBRID SUPER CAPACITORS:

\begin{tabular}{|c|l|l|l|l|l|}
\hline S.NO & PARAMETERS & BATTERIES & SUPER CAPACITORS & $\begin{array}{l}\text { HYBRID SUPER } \\
\text { CAPACITORS }\end{array}$ & REFERENCES \\
\hline $\mathbf{1 .}$ & Type of storage & Indirect Storage & Direct storage & Direct storage & Ref no:5 \\
\hline $\mathbf{2 .}$ & $\begin{array}{l}\text { Specific } \\
\text { /Gravimetric } \\
\text { Energy }\end{array}$ & $\begin{array}{l}\text { It is having very high } \\
\text { specific energy in } \\
\text { order of } 100 \text { to } 265 \\
\text { mWh/g. }\end{array}$ & $\begin{array}{l}\text { It is having less specific } \\
\text { energy and its value is } \\
\text { nearly } 4 \text { to } 9 \mathrm{mWh} / \mathrm{g} .\end{array}$ & $\begin{array}{l}\text { It is having medium } \\
\text { specific energy and its } \\
\text { value is nearly } 10 \text { to } 15 \\
\text { mWh/g. }\end{array}$ & Ref no:1 \\
\hline 3. & Specific power & $\begin{array}{l}\text { Its specific power is } \\
\text { less than } 0.3 \text { to } 1.5 \\
\text { W/g. }\end{array}$ & $\begin{array}{l}\text { It is having high specific } \\
\text { power up to } 3 \text { to } 10 \mathrm{~W} / \mathrm{g} .\end{array}$ & $\begin{array}{l}\text { It is having very high } \\
\text { specific power up to } 3 \text { to } \\
14 \text { W/g. }\end{array}$ & Ref no:2 \\
\hline
\end{tabular}


International Journal of Engineering Applied Sciences and Technology, 2019

Vol. 4, Issue 6, ISSN No. 2455-2143, Pages 114-119

Published Online October 2019 in IJEAST (http://www.ijeast.com)

\begin{tabular}{|c|c|c|c|c|c|}
\hline 4. & Discharge Time & $\begin{array}{l}\text { It is having more } \\
\text { discharging time and } \\
\text { it ranges from } 0.03 \text { to } \\
3 \text { hrs. }\end{array}$ & $\begin{array}{l}\text { Its discharging time is } \\
\text { less when compared to } \\
\text { batteries and it is in } \\
\text { between seconds to } \\
\text { minutes. }\end{array}$ & $\begin{array}{l}\text { It is having more } \\
\text { discharging time and it } \\
\text { ranges from } 1 \text { to } 2 \mathrm{hrs} \text {. }\end{array}$ & Ref no:2 \\
\hline 5. & Charging Time & $\begin{array}{l}\text { It's charging time is } \\
\text { also more in order of } \\
1 \text { to } 5 \text { hrs. }\end{array}$ & $\begin{array}{l}\text { It's charging time is also } \\
\text { less when compared to } \\
\text { batteries from seconds to } \\
\text { minutes. }\end{array}$ & $\begin{array}{l}\text { It's charging time is also } \\
\text { moderate when } \\
\text { compared to batteries } \\
\text { and it is in minutes. }\end{array}$ & Ref no:2 \\
\hline 6. & $\begin{array}{l}\text { Coloumbic } \\
\text { efficiency }\end{array}$ & $\begin{array}{l}\text { Its efficiency ranges } \\
\text { from } 70 \text { to } 85 \% \text {. }\end{array}$ & $\begin{array}{l}\text { Its efficiency is up to } \\
99 \% \text {. }\end{array}$ & $\begin{array}{l}\text { Its efficiency is up to } \\
90 \% \text {. }\end{array}$ & Ref no:2 \\
\hline 7. & Cycle life & $\begin{array}{l}\text { The life cycle of } \\
\text { batteries is very less } \\
\text { and it's around } 1000 .\end{array}$ & $\begin{array}{l}\text { These are having high } \\
\text { life cycle and it is above } \\
5,00,000 \text {. }\end{array}$ & $\begin{array}{l}\text { These are having } \\
\text { moderate life cycle and } \\
\text { it is about } 1,00,000 .\end{array}$ & Ref no:2 \\
\hline 9. & $\begin{array}{l}\text { Volumetric } \\
\text { Energy }\end{array}$ & $\begin{array}{l}\text { It is having high } \\
\text { volumetric energy of } \\
\text { about } 200 \text { to } 400 \\
\text { Wh/L. }\end{array}$ & $\begin{array}{l}\text { It is having less } \\
\text { volumetric energy and it } \\
\text { is found to be } 4 \text { to } 14 \\
\text { Wh/L. }\end{array}$ & $\begin{array}{l}\text { It is having medium } \\
\text { volumetric energy and it } \\
\text { is found to be } 49.66 \\
\mathrm{Wh} / \mathrm{L} \text {. }\end{array}$ & $\begin{array}{l}\text { Ref no:4, } \\
\text { Ref no:5 }\end{array}$ \\
\hline 10. & Voltage of a cell & $\begin{array}{l}\text { It is having high } \\
\text { voltages from } 2.5 \text { to } \\
4.2 \mathrm{v} \text {. }\end{array}$ & $\begin{array}{l}\text { It is having less voltage } \\
\text { from } 2.2 \text { to } 3.3 \mathrm{v} \text {. }\end{array}$ & $\begin{array}{l}\text { It is having medium } \\
\text { voltage from } 2.2 \text { to } 3.8 \mathrm{v} \text {. }\end{array}$ & Ref no:5 \\
\hline 11. & $\begin{array}{l}\text { Equivalent } \\
\text { Series Resistance }\end{array}$ & $\begin{array}{l}\text { The equivalent series } \\
\text { resistance value of } \\
\text { batteries high in order } \\
\text { of } 500 \mathrm{~m} \text {-ohms. }\end{array}$ & $\begin{array}{l}\text { The equivalent series } \\
\text { resistance value of super } \\
\text { capacitors is less in range } \\
\text { of } 40 \text { to } 300 \mathrm{~m} \text {-ohms. }\end{array}$ & $\begin{array}{l}\text { The equivalent series } \\
\text { resistance value of super } \\
\text { capacitors is very less in } \\
\text { range of } 0.37 \text { to } 1.89 \mathrm{~m} \text { - } \\
\text { ohms. }\end{array}$ & $\begin{array}{l}\text { Ref no:5, } \\
\text { Ref no:6 }\end{array}$ \\
\hline 12. & Life & $\begin{array}{l}\text { The life span of the } \\
\text { batteries is less in the } \\
\text { range of } 3 \text { to } 5 \text { years. }\end{array}$ & $\begin{array}{l}\text { The life span of the super } \\
\text { capacitors is more in } \\
\text { order of } 10-15 \text { years. }\end{array}$ & $\begin{array}{l}\text { The life span of the } \\
\text { super capacitors is in } \\
\text { order of } 5 \text { to } 10 \text { years }\end{array}$ & $\begin{array}{l}\text { Ref no:3, } \\
\text { Ref no:5 }\end{array}$ \\
\hline 13. & $\begin{array}{l}\text { Charge } \\
\text { temperature }\end{array}$ & $\begin{array}{l}\text { Its in range of } \\
0 \text { to } 45^{\circ} \mathrm{C}\end{array}$ & $\begin{array}{l}\text { It is in range of } \\
-40 \text { to } 65^{\circ} \mathrm{C} \text {. }\end{array}$ & $\begin{array}{l}\text { It is in range of } \\
-20 \text { to } 40^{\circ} \mathrm{C} \text {. }\end{array}$ & $\begin{array}{l}\text { Ref no:2, } \\
\text { Ref no:6 }\end{array}$ \\
\hline 14. & $\begin{array}{l}\text { Discharge } \\
\text { temperature }\end{array}$ & $\begin{array}{l}\text { It's in range of } \\
-20 \text { to } 60^{\circ} \mathrm{C} \text {. }\end{array}$ & $\begin{array}{l}\text { It's in range of } \\
-40 \text { to } 65^{\circ} \mathrm{C} \text {. }\end{array}$ & $\begin{array}{l}\text { It's in range of } \\
-20 \text { to } 70^{\circ} \mathrm{C} \text {. }\end{array}$ & $\begin{array}{l}\text { Ref no:1, } \\
\text { Ref no:6 }\end{array}$ \\
\hline
\end{tabular}


International Journal of Engineering Applied Sciences and Technology, 2019

Vol. 4, Issue 6, ISSN No. 2455-2143, Pages 114-119

Published Online October 2019 in IJEAST (http://www.ijeast.com)

\begin{tabular}{|c|l|l|l|l|l|}
\hline 15. & Risk of explosion & $\begin{array}{l}\text { There is more risk of } \\
\text { explosion in this type } \\
\text { of cell. }\end{array}$ & $\begin{array}{l}\text { There is no risk of } \\
\text { explosion in this type of } \\
\text { cell. }\end{array}$ & $\begin{array}{l}\text { There is no risk of } \\
\text { explosion in this type of } \\
\text { cell. Because they are } \\
\text { highly flexible. }\end{array}$ & $\begin{array}{l}\text { Ref no:2, } \\
\text { Ref no:6 }\end{array}$ \\
\hline
\end{tabular}

From the above data it is found that the hybrid super capacitors are having more advantages when compared to batteries and super capacitors. Due to this reasons hybrid super capacitors are having higher scope for ultimate power utilisation in near future.

\section{Keywords:}

Specific /Gravimetric Energy: It is defined as the battery capacity in terms of weight.

Coloumbic Efficiency: It is defined as the efficiency with which charge is transferred in a system during the electrochemical reaction. It is also called as Faraday's Efficiency.

Volumetric Energy: The amount of energy stored in a system per unit volume is called volumetric energy

\section{CLASSIFICATION OF SUPER CAPACITORS}

In order to increase the energy density the researcher's moved on to some latest technology in super capacitors this refers to hybrid super capacitors. Coming to hybrid super capacitors we higher energy densities and 3-4 times more voltage values when compared to super capacitors. These are cheaper in cost and light in weight compared to super capacitors [9-10].

Coming to super capacitors, supercapacitors can be classified according to its working principle as double layer Super-capacitor, Pseudo capacitors (or) Electro chemical supercapacitor and Hybrid super-capacitor as shown in Figure 8. The hybrid super-capacitor means has two different types of electrodes. One of them is double layer super-capacitor material such as active carbon; the other is electrochemical-super capacitor material such as ruthenium dioxide.

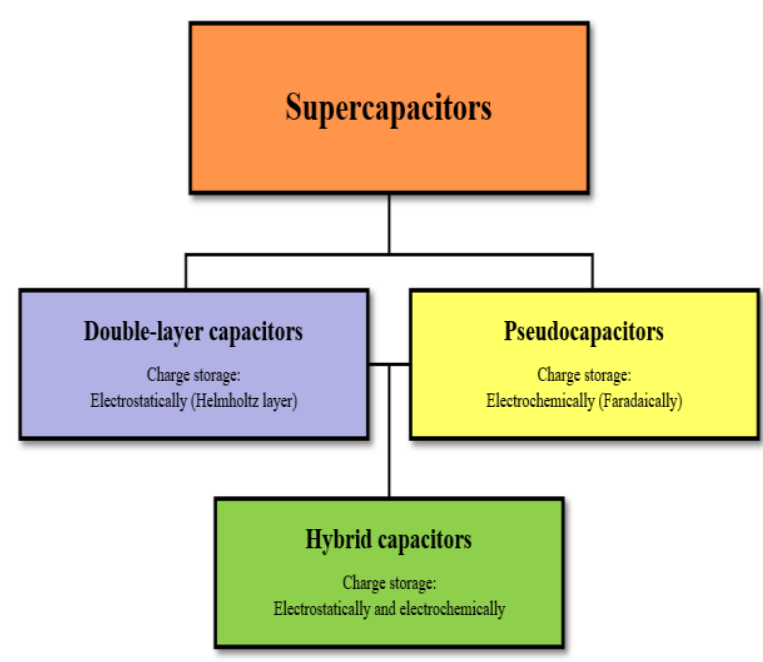

Figure 8

\section{HYBRID SUPER CAPACITORS}

These hybrid supercapacitors are mixture of both batteries and supercapacitors. As this energy storage system based on a battery electrode and a supercapacitor electrode called batterysupercapacitor hybrid (BSH)[11-13]. 


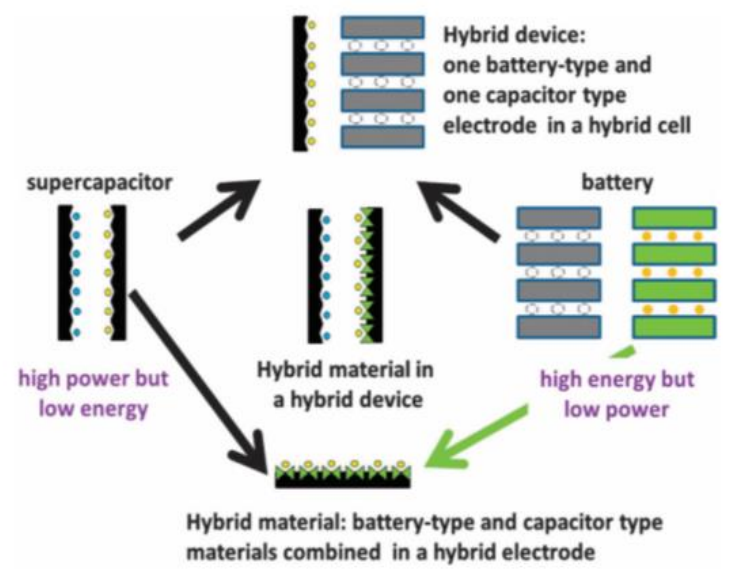

Figure 9

The above Figure 9 shows how the battery electrode and super capacitor electrode are kept to get hybrid super capacitors.

As it is the combination of both batteries and super capacitors it has high energy densities and high power densities. Below graph compares the energy densities and power densities of various energy storing devices such as batteries, super capacitors [14-16].

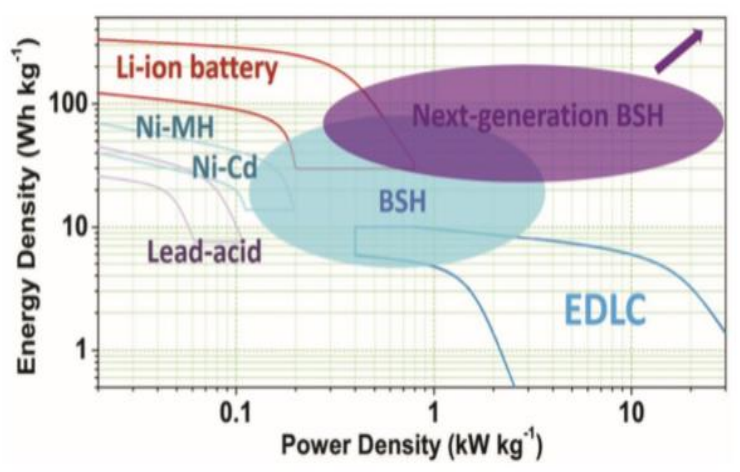

Figure 10

From the above Figure 10, it is found that hybrid supercapacitors are having higher power densities and energy densities than the other energy storing devices such as batteries and supercapacitors. The hybrid super capacitors are also called as BSH which means battery-super capacitor hybrid [17].

These Hybrid super capacitors (BSH) classified into several types based on the electrolyte components and specific energy storage mechanism. Li-ion BSH, Na-ion BSH, acidic BSH, alkaline BSH, BSH with redox electrolytes, and BSH with pseudocapacitive electrode and the above mentioned types are classified based on electrolytic components present in the BSH[18-20].
Acidic BSH's are usually obtained by combining lead acid battery and super capacitors. Alkali BSH's are formed by combining one alkaline type battery electrode and capacitive electrode and neutral electrolytes are employed for Na-ion and Li-ion BSHs. Coming to other types such as organic electrolytes and ionic electrolytes are volatile and flammable so gel-polymer type electrolyte is preferable in BSH because of its compatibility and safe energy storage and they are also popular for their flexibility and stretch ability. Aqueous BSHs are generally cheaper than the organic electrolyte and ionic based BSH's[21-22].

The electrolyte types and materials resources, aqueous BSH's (acidic/alkaline BSH, aqueous $\mathrm{Li}$-ion, and redox BSH's etc are more cheaper than organic electrolyte and ionic liquidbased BSH's and non Li-ion BSH's such as Na-ion BSH's used for long term applications and cheaper than all the above mentioned BSH's because sodium (Na) is abundantly available on our earth[23].

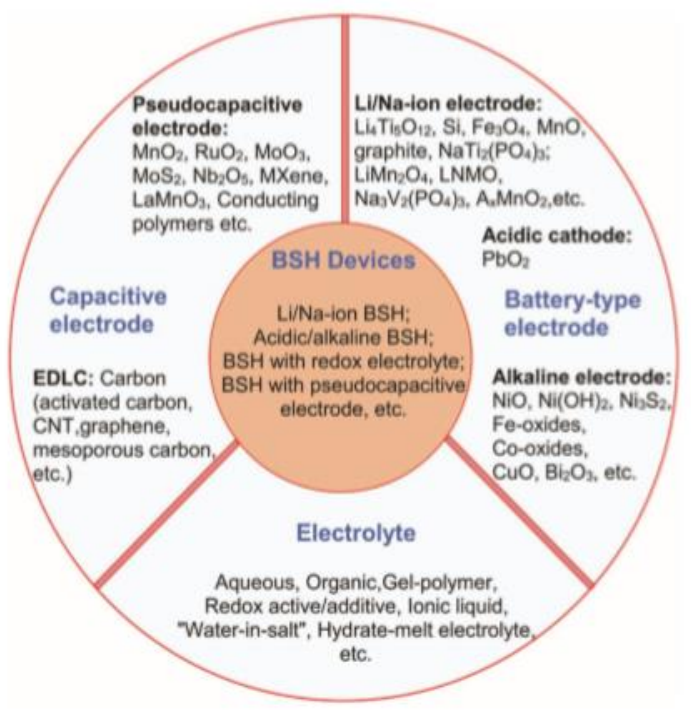

Figure 11

The above diagram 11 clearly represents different types of BSH devices and their classifications and the type of materials used in BSHs. For this above mentioned types Lithium based systems was the most popular one compare to others because of their high energy densities and some other chemical properties. So most of the researches are choosing this field which leads to the rapid growth of the Hybrid Supercapacitors. 


\section{International Journal of Engineering Applied Sciences and Technology, 2019 \\ Vol. 4, Issue 6, ISSN No. 2455-2143, Pages 114-119 \\ Published Online October 2019 in IJEAST (http://www.ijeast.com)}

\section{CONSTRUCTION AND WORKING OF HYBRID SUPER CAPACITORS}

The hollow nanostructures with complex shell structures are suitable for efficient energy storage of electrochemical energy [24]. Carbon based nano cubes are used for the formation of double shelled hollow structures surrounded by outer shells made of carbon sulphide as shown in the Figure 12. The special arrangements of subunits with different dimensions have high surface area, robustness which gives higher performance as a battery type electrode. Moreover a hybrid super capacitor is fabricated by using CoS-NP/CoS-NS as the positive electrode and the activated carbon as the negative electrode. These devices are operated table in a wide potential range of $1.6 \mathrm{v}$ with high energy and power density. This device is stable for 10,000 cycles with an extension of capacitance by $88 \%$.

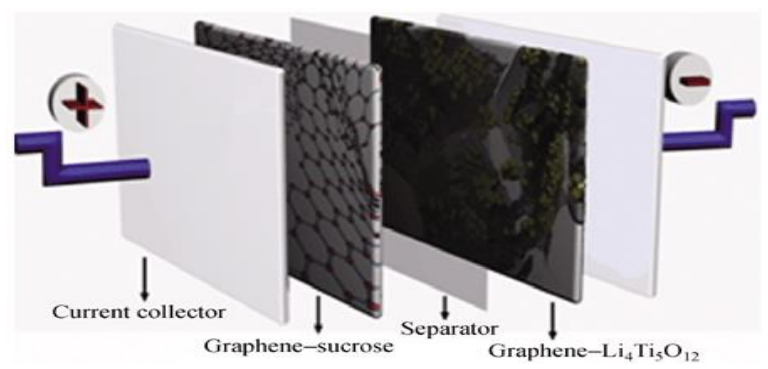

Figure 12

Lithium ion hybrid supercapacitors are also called as Li-ion capacitors ate highly preferable due to the combination of properties of battery and a super capacitor [25]. These are having high rapid charging and discharging, longer life cycles and higher energy storage.

Thus Li-ion hybrid super capacitors may become the ultimate power source for hybrid and electric vehicles in near future. In this graphene is used as an electrode material because of its properties like high surface area, higher electric conductivity, high electric stability and high thermal stability [26]. These are advantageous when compared to other electrode materials like activated carbon, graphite and metal oxides. The below Figure 12 represents how the hybrid super capacitors are made from batteries and capacitors.

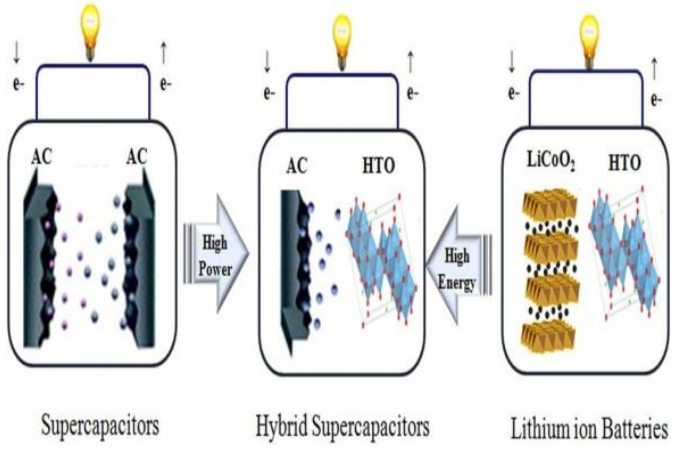

Fig: 5.2

\section{APPLICATIONS}

1. Hybrid Electric Vehicles

2. Micro grids

3. Energy Harvesting

4. Gondola

5. Railways

6. Uninterruptible power supply

Hybrid Electric Vehicles: These Super capacitors are used in electric vehicles increase the charging time, stable electrical properties, broader ranges of temperatures and longer lifetime when compared to batteries. On using these hybrid supercapacitors in hybrid electric vehicles braking energy is stored to improve driving efficiency [27]. This regenerative braking system is used to reduce fuel consumption in electric hybrid vehicles. Supercapacitors provide quick bursts of power, start-stop fuel saving system, faster start-stop with respect to traffic lights. The Figure 13 represents the various processes occurring in a hybrid vehicle.

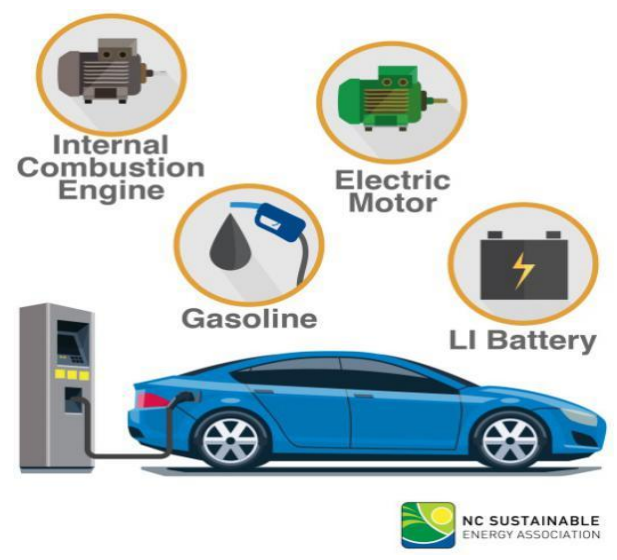

Figure 13

Micro grids: In micro grids, power is delivered by using clean and renewable energy as shown in the 


\section{International Journal of Engineering Applied Sciences and Technology, 2019 \\ Vol. 4, Issue 6, ISSN No. 2455-2143, Pages 114-119 \\ Published Online October 2019 in IJEAST (http://www.ijeast.com)}

Figure 14. Supercapacitors are used in microgrids to store the input power and deliver the power required during high demands and this reverse action takes place because of the presence of supercapacitors. Microgrids produce energy in the form of DC whereas supercapacitors are used for both AC and DC applications. These supercapacitors do not provide frequency when the grid is directly connected to the AC [27].

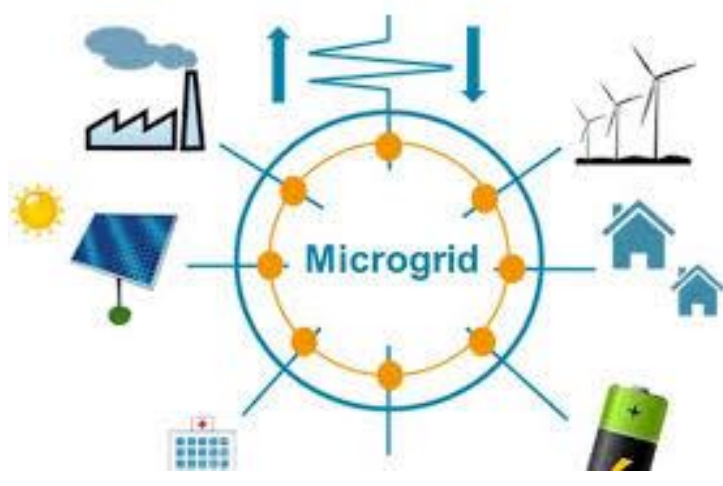

Figure 14

Energy Harvesting: Super capacitors are used in energy harvesting sector as shown in the Figure 15 because these are used to storing energy and discharging energy. Here the energy can be stored from different renewable like light energy, solar energy, wind energy and other forms of energy is converted into electrical energy. This stored energy will be released within 10 hours [27].

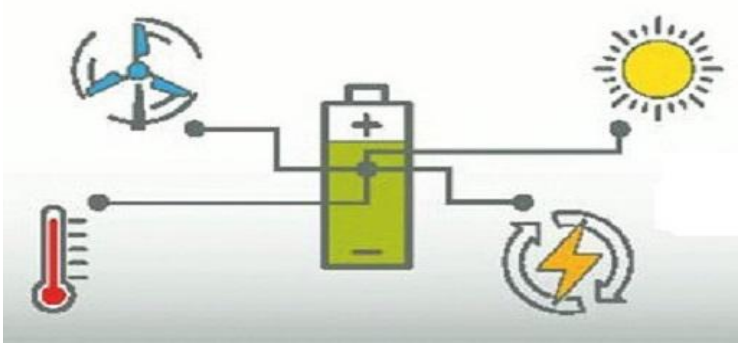

Figure 15

Gondola: These are used in faraway places from cities and are connected between mountains. These gondola use electricity for complete day for opening and closing the door, communication as shown in the Figure 16. These require very fast charging near the stations because it cannot be recharged when it is travelling. Supercapacitors are used in gondola for fast charging, more number of cycles and high lifetime [28].

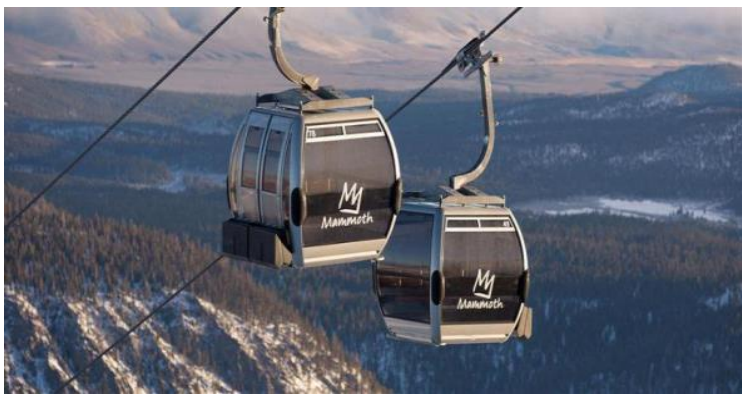

Figure 16

Railway: Supercapacitors are used in starting systems for railways for diesel electric transmission as shown in the Figure 17. These capacitors store braking energy and use it for regenerative action. These supercapacitors deliver peak current and magnetise the supply voltage. This is used in starting systems for diesel engines and increases the speed of the train. The use of supercapacitors in trains increases the efficiency [28].

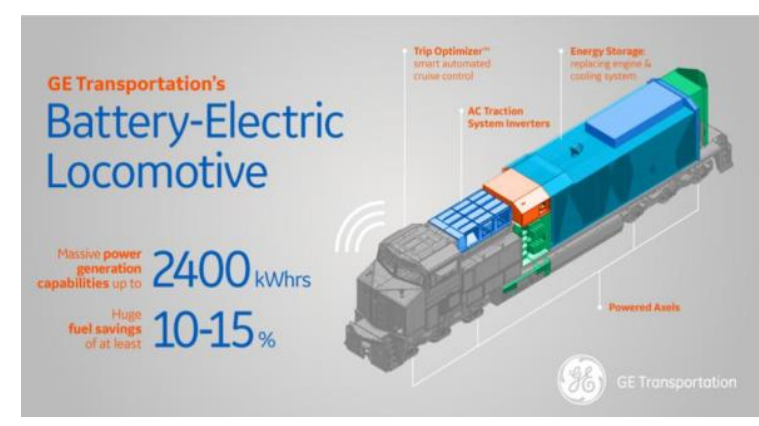

Figure 17

Uninterruptible power supplies (UPS): UPS systems are used to provide continuous and uninterruptible power supplies during peak loads by transferring power supply from the stored or backup energy system when any power disruption occurs. This type of energy transfer requires high energy density batteries so hybrid supercapacitors are highly preferable. There may be increase in battery losses and reduce the life cycle of the battery because of high pulsating currents. But hybrid supercapacitors can withstand high currents and their transients. These hybrid supercapacitors are used in UPS systems when backup system is required and for delivering power in short time. The Figure 18 represents the schematic process takes place for providing uninterrupted power supply. 


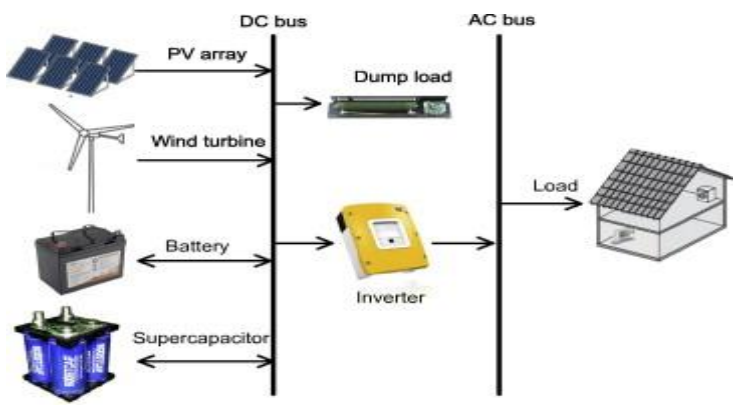

Figure 18

\section{CONCLUSION}

The review on the above article represents the current status of the hybrid supercapacitors and its future applications in various fields. The classification and principles of hybrid supercapacitors along with their mechanisms are reported in the article. In the field of electrification and transportation small electronic devices are used for storing large amounts of energy in shorter time but at low cost. The combination of Li-ion batteries and ultra-capacitors shows how efficiency and reliability of the source increases.

These hybrid super capacitors are suggested as best energy storing devices because of their higher energy and power densities. The applications of hybrid supercapacitors are especially used in field of hybrid electric vehicles, uninterruptible power supplies and energy harvesting; Super capacitors are more feasible and sustainable energy storing devices when compared to other energy storing devices like Li-ion batteries, capacitors and supercapacitors. These supercapacitors are fabricated through different types of materials to avoid losses due to resistance and leakage currents. The developments of hybrid super capacitors using different materials have great extent in future.

\section{ACKNOWLEDGEMENT}

I take this opportunity to express my deep sense of gratitude towards my guide Dr.D.Danalakshmi, Associate Professor, Department of Electrical Engineering, GMRIT.I extend my sincere thanks to Dr.B.Bharani Chandra Kumar .Head of the Electrical department, GMRIT. Their motivation, Patience and their encouragement has benefited us to do this research work.

\section{REFERENES}

1. Paladini, V., Donateo, T., De Risi, A., \& Laforgia, D. (2007). Super-capacitors fuel-cell hybrid electric vehicle optimization and control strategy development. Energy
Conversion and Management, 48(11), 30013008.

2. Pandolfo, A. G., \& Hollenkamp, A. F. (2006). Carbon properties and their role in supercapacitors. Journal of power sources, 157(1), 11-27.

3. Miller, J. R., \& Burke, A. F. (2008). Electrochemical capacitors: challenges and opportunities for real-world applications. The Electrochemical Society Interface, 17(1), 53.

4. Wang, G., Zhang, L., \& Zhang, J. (2012). A review of electrode materials for electrochemical supercapacitors. Chemical Society Reviews, 41(2), 797-828.

5. Zhong, C., Deng, Y., Hu, W., Qiao, J., Zhang, L., \& Zhang, J. (2015). A review of electrolyte materials and compositions for electrochemical supercapacitors. Chemical

Society Reviews, 44(21), 7484-7539.

6. Ding, J., Hu, W., Paek, E., \& Mitlin, D. (2018). Review of hybrid ion capacitors: from aqueous to lithium to sodium. Chemical reviews, 118(14), 6457-6498.

7. Palma Fanjul, L. M. (2004). Some new applications of supercapacitors in power electronic systems (Doctoral dissertation, Texas A\&M University).

8. Wang, Y., Song, Y., \& Xia, Y. (2016). Electrochemical capacitors: mechanism, materials, systems, characterization and applications. Chemical Society Reviews, 45(21), 5925-5950.

9. Díaz-González, F., Sumper, A., GomisBellmunt, O., \& Villafáfila-Robles, R. (2012). A review of energy storage technologies for wind power applications. Renewable and sustainable energy reviews, 16(4), 2154-2171.

10. Dubal, D. P., Ayyad, O., Ruiz, V., \& GomezRomero, P. (2015). Hybrid energy storage: the merging of battery and supercapacitor chemistries. Chemical Society Reviews, 44(7), 1777-1790.

11. Johansson, T. B., Kelly, H., Reddy, A. K., \& Williams, R. H. (1993). Renewable energy: sources for fuels and electricity.

12. Hannan, M. A., Azidin, F. A., \& Mohamed, A. (2014). Hybrid electric vehicles and their challenges: A review. Renewable and Sustainable Energy Reviews, 29, 135-150..

13. Su, X., Wu, Q., Li, J., Xiao, X., Lott, A., Lu, W., ... \& Wu, J. (2014). Silicon-based nanomaterials for lithium-ion batteries: a review. Advanced Energy Materials, 4(1), 1300882. 


\section{International Journal of Engineering Applied Sciences and Technology, 2019 Vol. 4, Issue 6, ISSN No. 2455-2143, Pages 114-119 \\ Published Online October 2019 in IJEAST (http://www.ijeast.com)}

14. González, A., Goikolea, E., Barrena, J. A., \& Mysyk, R. (2016). Review on supercapacitors: technologies and materials. Renewable and Sustainable Energy Reviews, 58, 1189-1206.

15. Mike, J. F., \& Lutkenhaus, J. L. (2013). Recent advances in conjugated polymer energy storage. Journal of Polymer Science Part B: Polymer Physics, 51(7), 468-480.

16. Vlad, A., Singh, N., Rolland, J., Melinte, S., Ajayan, P. M., \& Gohy, J. F. (2014). Hybrid supercapacitor-battery materials for fast electrochemical charge storage. Scientific reports, $4,4315$.

17. Devillers, N., Jemei, S., Péra, M. C., Bienaimé, D., \& Gustin, F. (2014). Review of characterization methods for supercapacitor modelling. Journal of Power Sources, 246, 596-608.

18. Sevilla, M., \& Mokaya, R. (2014). Energy storage applications of activated carbons: supercapacitors and hydrogen storage. Energy \& Environmental Science, 7(4), 1250-1280.

19. Malak, A., Fic, K., Lota, G., Vix-Guterl, C. and Frackowiak, E., 2010. Hybrid materials for supercapacitor application. Journal of Solid State Electrochemistry, 14(5), pp.811-816.

20. Ghosh, A., \& Lee, Y. H. (2012). Carbon-based electrochemical capacitors. ChemSusChem, 5(3), 480-499.

21. Staaf, L. G. H., Lundgren, P., \& Enoksson, P. (2014). Present and future supercapacitor carbon electrode materials for improved energy storage used in intelligent wireless sensor systems. Nano Energy, 9, 128-141.

22. Wang, H., Zhu, C., Chao, D., Yan, Q., \& Fan, H. J. (2017). Nonaqueous hybrid lithium-ion and sodium-ion capacitors. Advanced Materials, 29(46), 1702093.

23. Cuentas-Gallegos, A. K., Pacheco-Catalán, D., \& Miranda-Hernández, M. (2017). Environmentally friendly supercapacitors. Materials for Sustainable Energy Applications: Conversion, Storage, Transmission, and Consumption, 351.

24. Mensah-Darkwa, K., Zequine, C., Kahol, P. K., \& Gupta, R. K. (2019). Supercapacitor energy storage device using biowastes: a sustainable approach to green energy. Sustainability, 11(2), 414.

25. Thounthong, P., Rael, S., \& Davat, B. (2009). Energy management of fuel cell/battery/supercapacitor hybrid power source for vehicle applications. Journal of Power Sources, 193(1), 376-385.
26. Du Pasquier, A., Plitz, I., Menocal, S., \& Amatucci, G. (2003). A comparative study of Li-ion battery, supercapacitor and nonaqueous asymmetric hybrid devices for automotive applications. Journal of power sources, 115(1), 171-178.

27. Thavasi, V., Singh, G., \& Ramakrishna, S. (2008). Electrospun nanofibers in energy and environmental applications. Energy \& Environmental Science, 1(2), 205-221.

28. Halper, M. S., \& Ellenbogen, J. C. (2006). Supercapacitors: A brief overview. The MITRE Corporation, McLean, Virginia, USA, 1-34. 